\title{
再生医療製品の品質評価におけるグライコミクス
}

橋井則 貴, 中澤志織, 川崎ナナ*

\section{Glycomics in Quality Control of Tissue-engineered Medical Products}

\author{
Noritaka Hashii, Shiori Nakazawa, and Nana Kawasaki* \\ National Institute of Health Sciences; 1-18-1 Kamiyoga, Setagaya-ku, Tokyo 158-8501, Japan.
}

(Received December 2, 2011)

\begin{abstract}
Glycosylation of cells is known to alter with several biological events such as cell differentiations and proliferations as well as some diseases. "Glycomic approaches", comprehensive qualitative and quantitative glycan analyses of the cells, have become increasingly important as a means of discovering biomarkers that have the potential of being used as disease diagnostic markers and molecular markers for cell characterizations. In this paper, we introduce a method of quantitative glycan profiling by liquid chromatography/mass spectrometry with a combination of an isotope tagging method. In addition, we demonstrate the potential of glycan profiling as a tool for the identification of differentiated human bone marrow mesenchymal stem cell (hMSC) and non-differentiated hMSC.
\end{abstract}

Key words_- glycan profiling; quantitative glycan analysis; isotope tagging method

\section{1.はじめに}

細胞に存在するタンパク質の多くは糖タンパク質 であり，糖鎖部分の構造や分布は，がんや自己免疫 疾患などある種の疾患, 細胞分化等の生命現象, あ るいは細胞環境の変化などに伴い変化することが知 られている. ${ }^{1-6)}$ がん化や分化の過程で変動する糖 鎖を見い出すことは，疾患の診断マーカーや細胞の 分子マーカーの開発等につながる可能性がある．糖 鎖は遺伝子の直接的な産物ではなく，様々な酵素反 応を経て生合成される二次的産物であるため, 遺伝 子解析から構造や分布の変化を推定することは容易 ではない，糖鎖の変化を明らかにするためには，表 現型である細胞中の糖鎖を直接解析することが肝要 であり，細胞糖鎖（グライコーム）の質的・量的な 変化を網羅的に解析するグライコミクスに高い関心 が集まっている.

グライコーム解析の手法として，レクチンを用い る方法, キャピラリー電気泳動法, 質量分析法 (MS)，及び蛍光標識 HPLC を用いる方法などがあ

国立医薬品食品衛生研究所（T158-8501 東京都世田谷 区上用賀 1-18-1)

*e-mail: nana@nihs.go.jp

本総説は, 日本薬学会第 131 年会シンポジウムS16 で 発表したものを中心に記述したものである.
る.7これまでにわれわれは，液体クロマトグラフ ィー/質量分析（LC/MS）を用いた糖鎖プロファイ リング法を開発し，疾患モデルマウスのグライコー ム解析などに応用してきた。 ${ }^{8,9)}$ 本分析法は，遊離糖 鎖の還元末端を誘導体化し，グラファイトカーボン カラムを用いた LC により糖鎖を微細構造の違いで 分離しながら，オンラインによる分子の質量測定, 並びに多段階質量分析（MS $\left.{ }^{\mathrm{n}}\right)$ を行い，糖鎖の分布 と各糖鎖の構造を推定する方法である. ${ }^{9,10)}$ 本稿で は，本分析法を再生医療での応用が期待されている 同種体性幹細胞のグライコーム解析に応用した例を 紹介する.

\section{2. ヒト間葉系幹細胞の糖鎖プロファイリング}

ヒト幹細胞を用いる臨床研究は, 臟器機能再生等 を通じて国民の健康の維持並びに疾病の予防，診断 及び治療に重要な役割を果たすものと考えられてお り，2006 年 7 月の「ヒト幹細胞を用いた臨床研究 に関する指針」の施行以後，2011 年 3 月現在， 28 件の臨床研究が承認されている。 これらを再生医療 品開発につなげるためには，品質管理の一環とし $\tau$, 適切な生化学的指標, 免疫学的指標, 特徵的産 生物質など適切な遺伝型あるいは表現型の指標を選 択して，目的とする細胞・組織であることを確認す るための手法を確立する必要がある，細胞の糖鎖は 
がん化や分化などに伴い変化することから，目的と する細胞・組織の評価指標の 1 つとして利用できる 可能性が高い.

Figure 1 は, 再生医療への応用が期待されている ヒト骨䯣由来間葉系幹細胞 (hMSC) の糖鎖プロフ アイルである。 hMSC は，多能性を有する体性幹 細胞であり，骨，軟骨，脂肪及び神経様の細胞に分 化することが知られている. ${ }^{11,12)}$ iPS 細胞や hMSC などが再生医療製品として応用可能になったとき， 特性解析や品質管理等に利用できる細胞数には制限 があると予想されることから, 微量分析が可能な試 験法の設定が求められる。LC/MS により，わずか $2 \times 10^{5}$ 個の $\mathrm{hMSC}$ から糖鎖分布を示すトータルイ オンカレントクロマトグラム（TICC）を得ること ができた．実線は，ポジティブイオンモードにより 得られた TICC で，主に中性糖鎖（高マンノース
型，パウチマンノース型糖鎖，混成型，及びアシア 口複合型糖鎖）の分布を示している．破線は，ネガ ティブイオンモードで得られた TICC で，酸性糖鎖 （シアロ糖鎖）の分布を示している. Figure 1 中の 糖鎖構造は，各ピークに含まれる主な糖鎖の推定構 造であり，MS によるフルスキャン $(m / z$ 700-2000) で得られた分子関連イオンの質量と $\mathrm{MS}^{\mathrm{n}}$ により取 得されたプロダクトイオンの質量から推定している. hMSC に結合している糖鎖の種類は, 高マンノー ス型糖鎖，パウチマンノース型糖鎖，混成型糖鎖， 及び複合型糖鎖と幅広く, 複合型糖鎖には $N$ アセ チルノイラミン酸（NeuNAc） とフコース（Fuc） の結合数に不均一性がみられる。 LC/MS で得られ るピーク間の強度比は，糖鎖の結合比を正確には反 映していないが，ピークのパターンから，中性糖鎖 では高マンノース型糖鎖 M8 及び M9 が多いこと

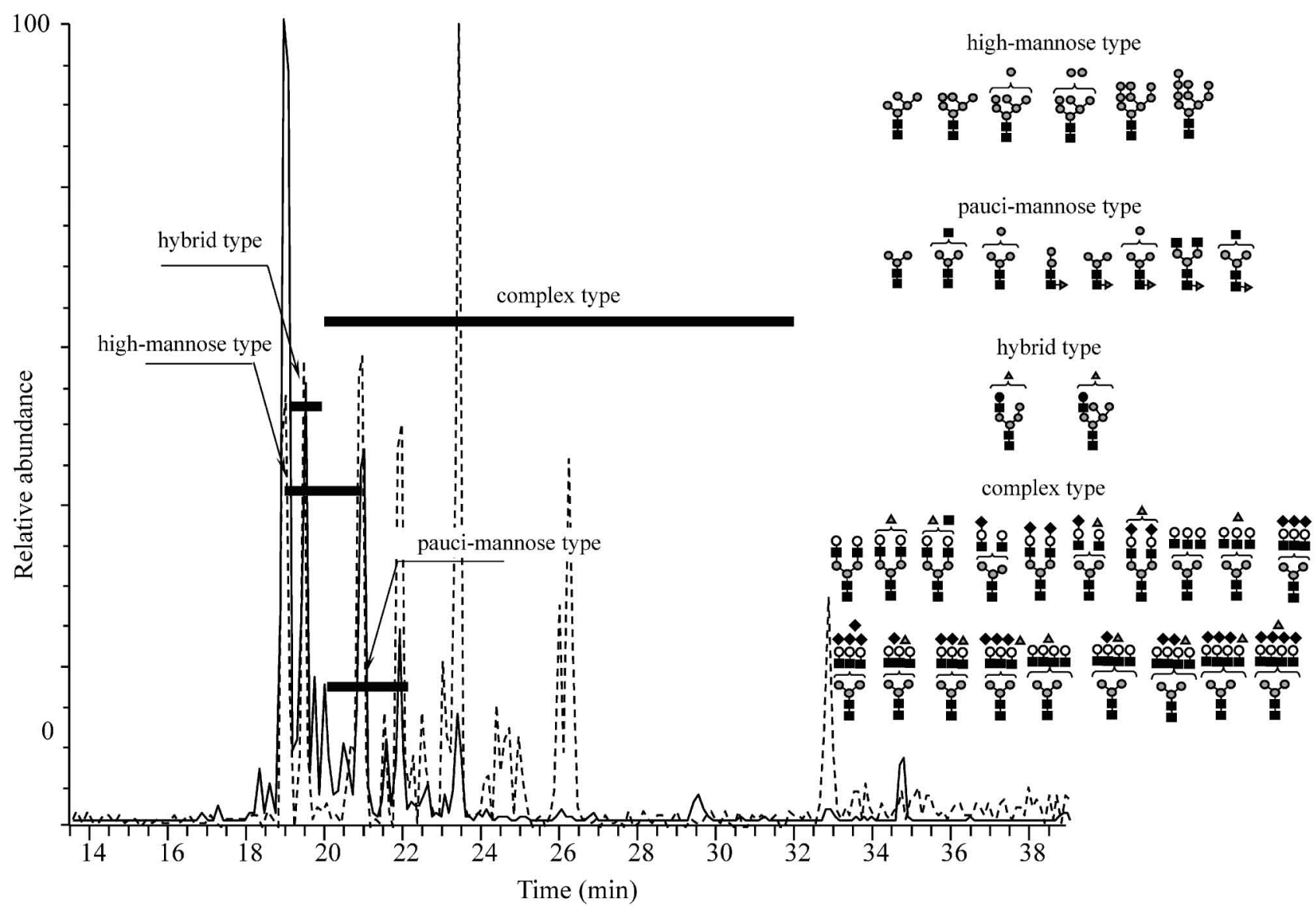

Fig. 1. Total Ion Current Chromatogram (TICC) Obtained by LC/MS of Reduced N-linked Glycans Prepared from hMSC The solid line and the dashed line denote chromatograms obtained by LC/MS in the positive ion mode and the negative ion mode, respectively. LC, Paradigm MS4 HPLC system (Michrom BioResources); MS, LTQ-FT (Thermo Fisher Scientific); column, graphitized carbon column $(0.075 \times 150 \mathrm{~mm}$; particle size, $5 \mu \mathrm{m}$ ); mobile phase, $5 \mathrm{~mm}$ ammonium bicarbonate containing $2 \%$ acetonitrile (A buffer) and $5 \mathrm{~mm}$ ammonium bicarbonate containing $80 \%$ acetonitrile (B buffer); flow rate, $300 \mathrm{~nL} / \mathrm{min}$; gradient condition, $2-45 \% \mathrm{~B}$ buffer $(60 \mathrm{~min})$; electrospray voltage, $2.5 \mathrm{kV}$ in the positive and negative ion modes. $\Delta$, fucose (Fuc); (Man); $\bigcirc$, galactose (Gal); $\mathbf{\square}, N$-acetylglucosamine (GlcNAc); $\diamond, N$-acetylneuraminic acid (NeuNAc) . 

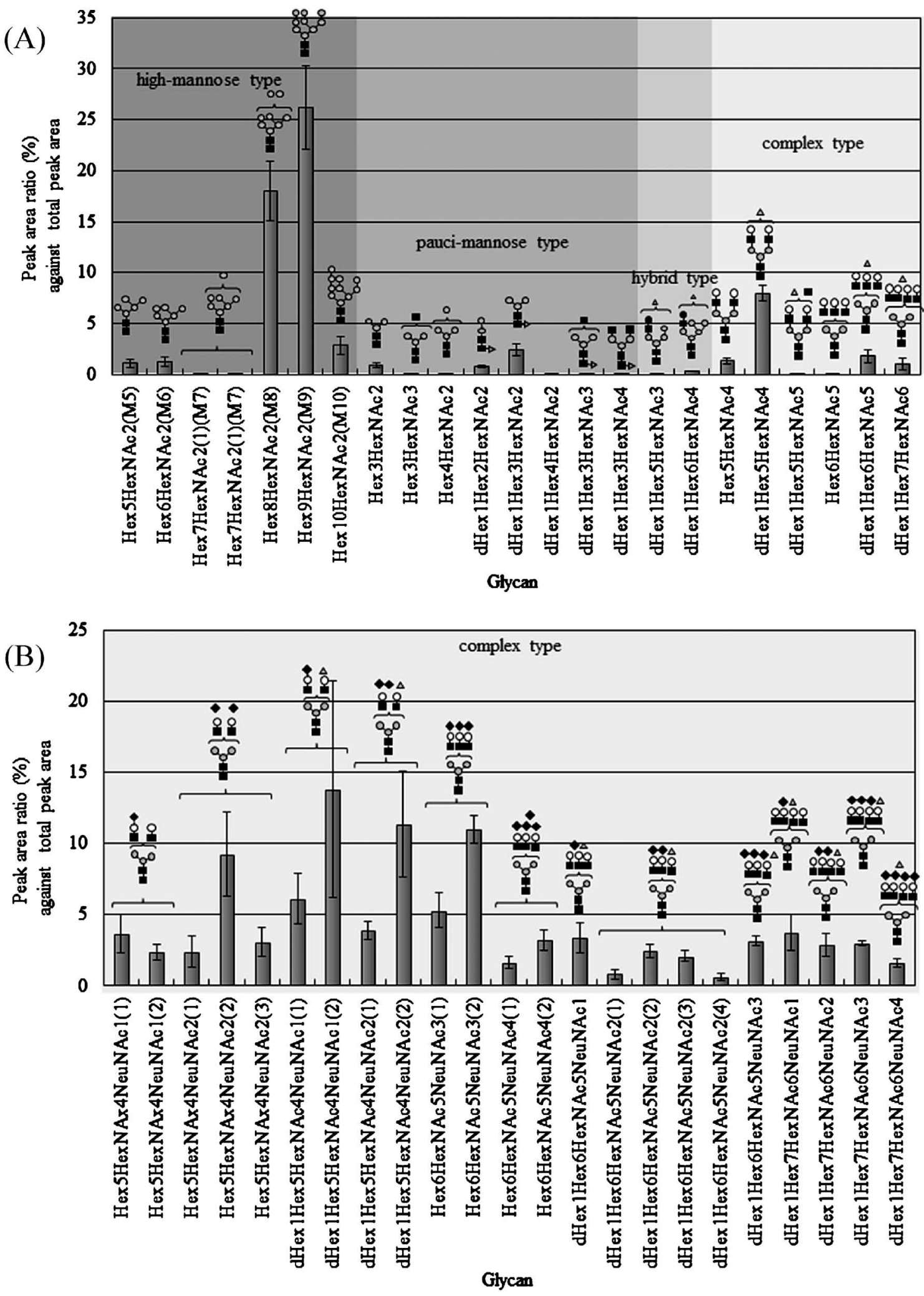

Fig. 2. Glycan Distribution in hMSC

The relative peak intensity of each glycan is expressed as a percentage of the total peak intensity of the glycans. Error bars represent the standard deviations. (A) , Distribution of neutral glycans (positive ion mode); (B), distribution of sialylated glycans (negative ion mode). dHex, deoxyhexose; Hex, hexose; HexNAc, $N$-acetylhexosamine: NeuNAc, $N$-acetylneuraminic acid. 
[Fig. 2(A) ]，また，酸性糖鎖では，生合成後期に あらわれる分岐鎖の多い糖鎖が少ないことが示唆さ れた [Fig. 2(B)].

\section{3. 細胞発現糖鎖の比較定量解析}

Figure 3(A) は, 未処理 hMSC の光学顕微鏡像で ある. hMSC を骨細胞に分化誘導し，顕微鏡によ り形態学的な変化を観察すると, 14 日目からカル シウムの沈着が観察され, 誘導後 21 日目には, 細 胞の約 70\%にカルシウムの沈着がみられる [Fig. 3 (B) ]. 脂肪細胞への分化では, 誘導開始 7 日目か ら脂肪滴が観察され始め, 21 日目には多くの細胞 で脂肪滴の蓄積が観察される $[$ Fig. 3(C)]. Figure 3 (D) は MSCを神経様細胞に分化誘導後 2 日目の 細胞であり, 細胞質部分の繊維状から球状への変 化, 及び突起の伸長が観察され, 神経細胞の形態学 的な特徵を有していることがわかる.これらの分化 を評価する方法として, 免疫組織化学染色法やフ ローサイトメトリー法などにより, 分化細胞に特異 的に発現するタンパク質の発現の有無を確認する方 法が知られている. しかし, 神経様分化細胞のマー カーとして使用されているタンパク質の多くは未分 化の hMSC にも発現されており, 特異性に課題が あることが指摘されている. ${ }^{13)} \mathrm{hMSC}$ とその神経様 分化細胞で結合量に差異が認められる糖鎖を見い出 すことができれば，より特異性の高いマーカーとし
て利用できる可能性がある. そのためには, 神経様 分化前後の細胞の糖鎖分布を比較できる定量的解析 手法が必要である.

LC/MS では, ピーク強度の再現性に依然として 問題があり, 複数のサンプル間で量的な比較を行う ためには，同位体標識法や，統計的解析手法を用い る必要がある，筆者らは，重水素（D）置換 2-アミ ノピリジン（2AP）により調製した 4D 置換ピリジ ルアミノ化（PA）糖鎖を用いた比較定量法を開発 している (Fig. 4). 14)この方法は, 比較する試料 A 並びに B から酵素的あるいは化学的に糖鎖を切り 出し，それぞれ D 未置換 $\mathrm{PA}$ 糖鎖 $\left(\mathrm{d}_{0}-\mathrm{PA}\right.$ 糖鎖 $)$ 並びに $\mathrm{d}_{4}-\mathrm{PA}$ 糖鎖とし, 混合して LC/MS で分析 する方法である $\left[\right.$ Fig. 4(A) ]。 $\mathrm{d}_{0}-\mathrm{PA}$ 糖鎖と $\mathrm{d}_{4}-\mathrm{PA}$ 糖鎖は, 糖鎖部分の構造の差異に基づいて分離され るが [Fig. 4(B)], マススペクトル上, 質量 $4 \mathrm{u}$ 差 のイオンとして分離される $[\mathrm{Fig} .4(\mathrm{C})]$. 糖鎖量の 違いはピーク強度の違いとなってあらわれるので, ピーク強度比を求めることにより, 糖鎖結合比を得 ることができる.

われわれの報告に続き, D 標識された 1-フエニ ル-3-メチル-5-ピラゾロン (PMP) や ${ }^{13} \mathrm{C}$ で標識し たアラニン，2-アミノ安息香酸を用いて還元末端を 標識する方法が相次いで報告された（Table 1)。ま た ${ }^{13} \mathrm{C}$ で標識されたヨウ化メチルで糖鎖を全メチル

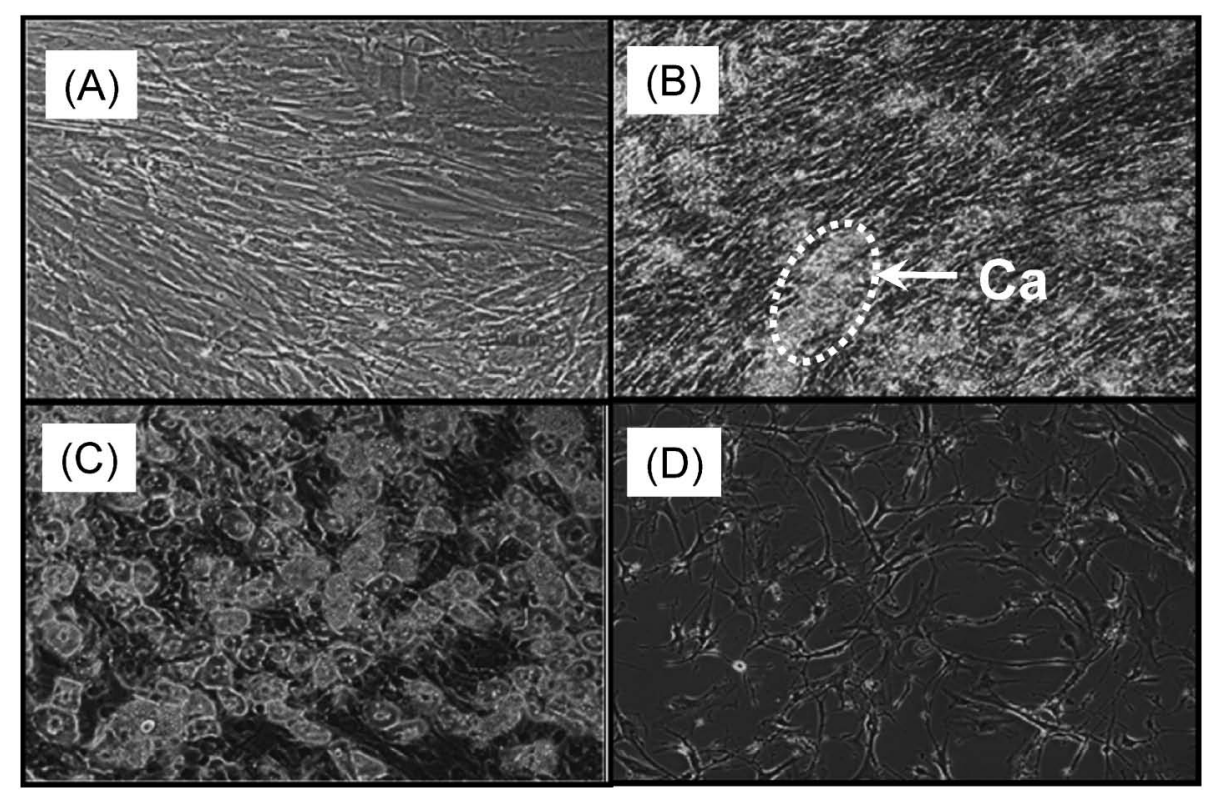

Fig. 3. Cell Images of hMSC and Its Differentiated Cells Taken by a Light Microscope (A), hMSC; (B), osteogenic differentiation; (C), adipogenic differentiation; (D), neural differentiation. 
(A)

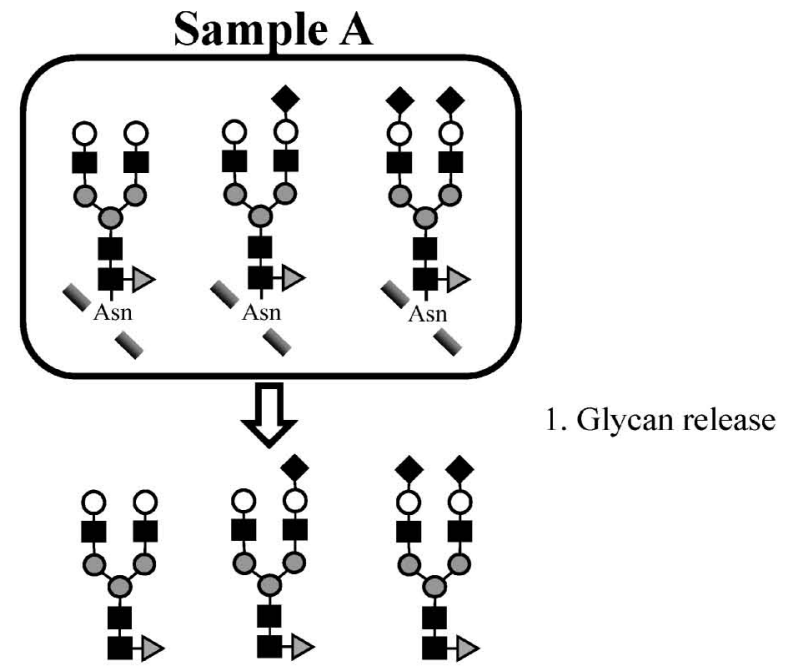

Glycan 1 Glycan 2 Glycan 3
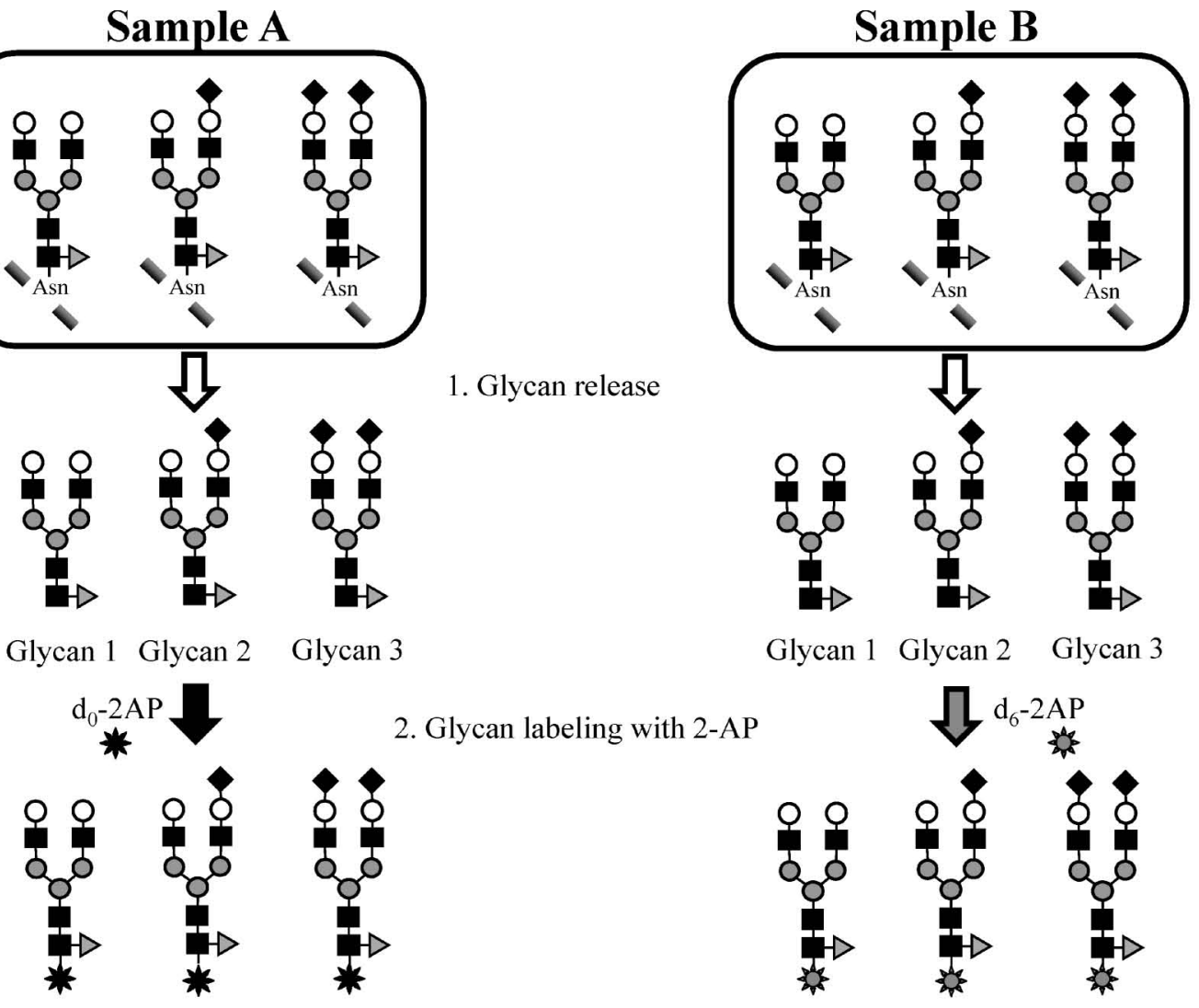

2. Glycan labeling with 2-AP

Glycan 1 Glycan 2 Glycan 3

Glycan A1 Glycan A2 Glycan A3

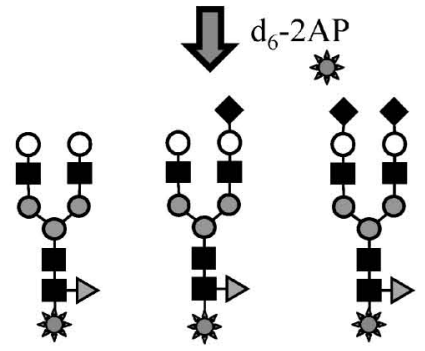

$\mathrm{d}_{0}$-PA-glycans 3. Mixing

(B)
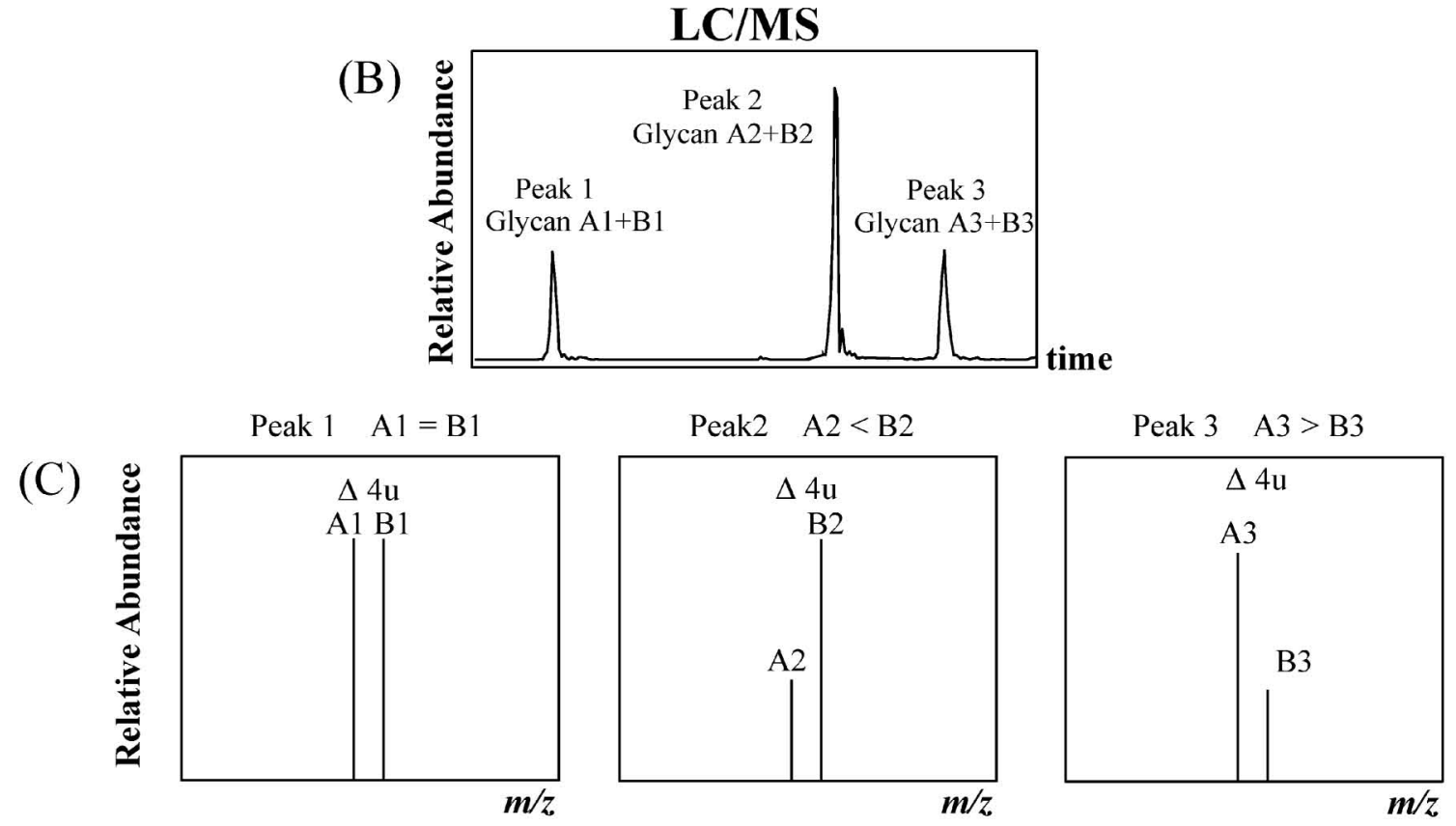

Fig. 4. Quantitative Glycan Analysis by a Combination of Isotope Tagging Method

(A), Strategy for quantitative glycan analysis using $\mathrm{d}_{0^{-}} 2 \mathrm{AP}$ and $\mathrm{d}_{6}-2 \mathrm{AP}$ as labeling reagents; (B), chromatogram obtained by the LC/MS of a mixture of $\mathrm{d}_{0^{-}}$ $\mathrm{PA}$ and $\mathrm{d}_{4}$-PA-glycans; $(\mathrm{C})$, mass spectra obtained from a mixture of $\mathrm{d}_{0}-\mathrm{PA}$ and $\mathrm{d}_{4}$-PA-glycans. 


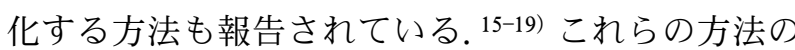
多くは，酸性溶液中で加熱して糖鎖を誘導体化する 方法であり，シアル酸が解離する可能性があること から，シアロ糖鎖が多いhMSC には適切でない． そこでわれわれは，中性水溶液中で標識が可能なフ エニルヒドラジン（PHN）を用いた，新たな糖鎖 同位体標識法を開発した [Fig. 5(A) ]. ${ }^{21)}$ この方法 は，糖鎖試料溶液に，六炭素が ${ }^{13} \mathrm{C}$ で置換された PHN $\left({ }^{13} \mathrm{C}_{6}\right.$-PHN) 塩酸塩又は未置換 PHN $\left({ }^{12} \mathrm{C}_{6}\right.$ PHN）塩酸塩，並びに還元剤 2-ピコリンボランを 加えて遮光下 $55^{\circ} \mathrm{C}$ で 1 時間程度反応させる方法で ある $[$ Fig. 5(B) ]. 22,23) 反応終了後，クロロホルム 抽出により，過剩な PHN 及び 2-ピコリボランを除 くことができるので, 標識後の後処理も簡単である.

Figure 6 は，ジシアロ 2 本鎖糖鎖の ${ }^{12} \mathrm{C}_{6}-\mathrm{PHN}$ 標識 体及び ${ }^{13} \mathrm{C}_{6}-\mathrm{PHN}$ 標識体の等量混合物のマススペク トルであり， $m / z 1231.5$ 及び $m / z 1234.5$ に，それ ぞれ ${ }^{12} \mathrm{C}_{6}$-PHN 標識体及び ${ }^{13} \mathrm{C}_{6}$-PHN 標識体の 2 価 イオンが観測されている。両者の質量差は $6 \mathrm{u}$ であ り, 天然に存在する同位体の影響は少ない。

この PHN 標識法と LC/MS を用いて，未分化 hMSC と神経様に分化した hMSC の糖鎖結合量を 比較定量した結果が Fig. 7 である. 上向きのカラ ムは未分化細胞よりも神経様分化細胞で多かった糖 鎖で，未分化細胞の糖鎖を 1.0 としたときの相対 比，また，下向きのカラムは神経様細胞よりも未分 化細胞で多かった糖鎖で，神経様分化細胞の糖鎖を 1.0 としたときの相対比を表している. hMSC を神 経様細胞に分化誘導すると，Fuc 結合複合型糖鎖の 高分岐化が進む一方で， 3 及び 4 個の NeuNAc が 結合し，かつ Fuc が結合していない複合型 3 本鎖 糖鎖の割合は減少する傾向にあることがわかる。こ の結果は，hMSC の神経様分化において，2 日間で 糖鎖のプロファイルが変わること，換言すれば，糖 鎖プロファイルを比べることによって，未分化細胞 と神経様分化細胞を識別できる可能性を示唆してい ると思われる。

\section{4. おわりに}

本稿では，再生医療での応用が期待されている hMSC を用いて，LC/MS によるグライコーム解析 法が，細胞分化の評価に応用できる可能性があるこ とを示した．これまでグラコミクスは，主にがんな ぞの診断マーカー探索研究の 1 つとして展開されて

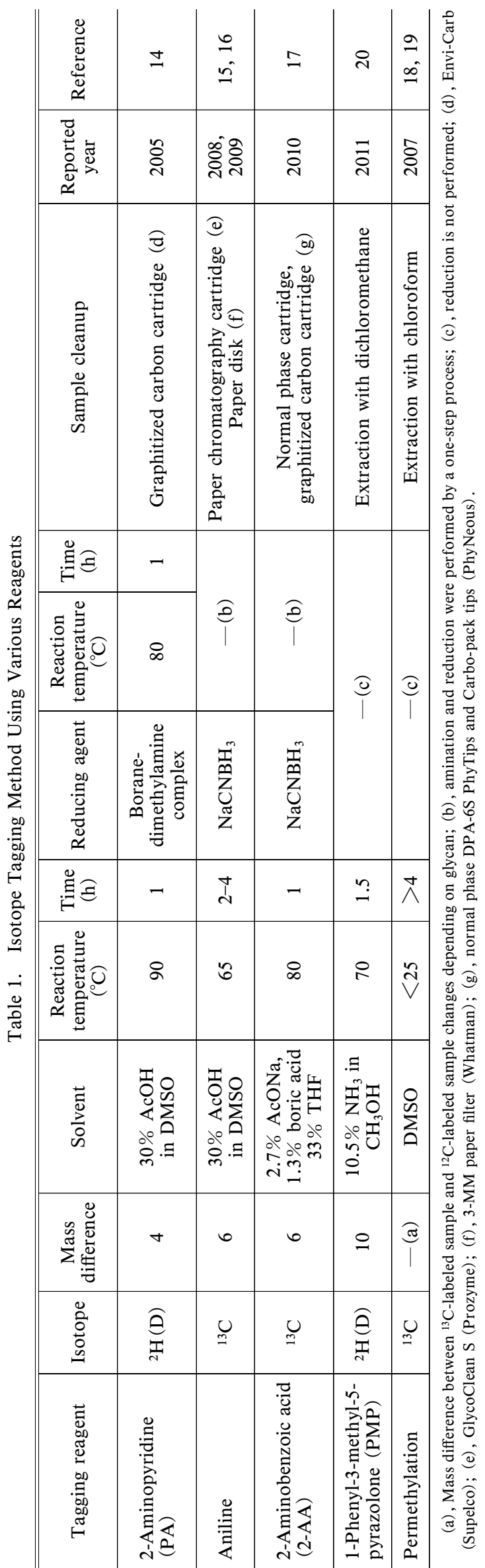


(A)

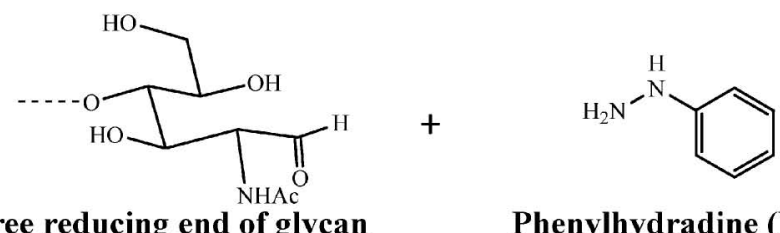

Free reducing end of glycan

Phenylhydradine (PHN)

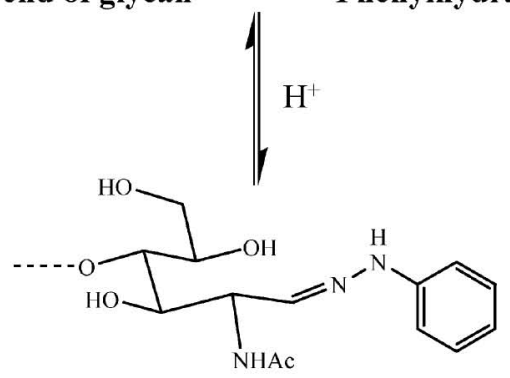

Phenylhydrazone

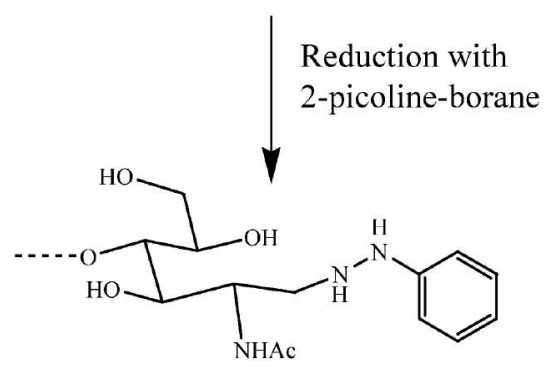

PHN-labeled Glycan

(B)
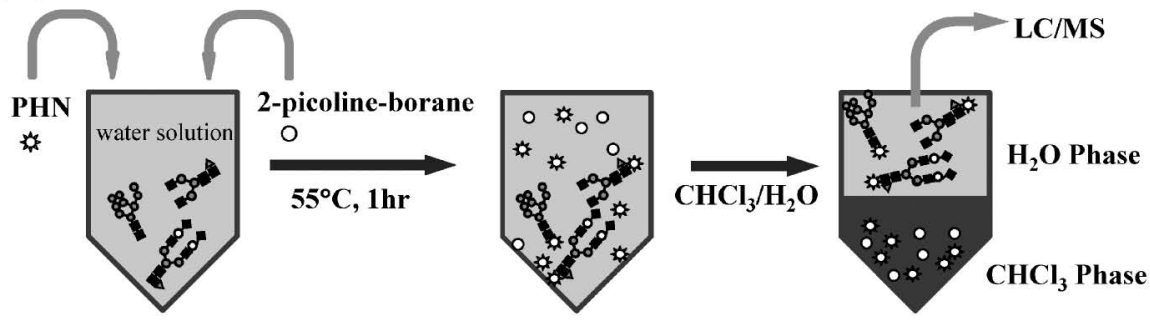

Fig. 5. Tagging of Glycan with Phenylhydrazine (PHN)

(A), Reaction mechanism of glycan tagging with PHN; (B), preparation of PHN labeled glycan.

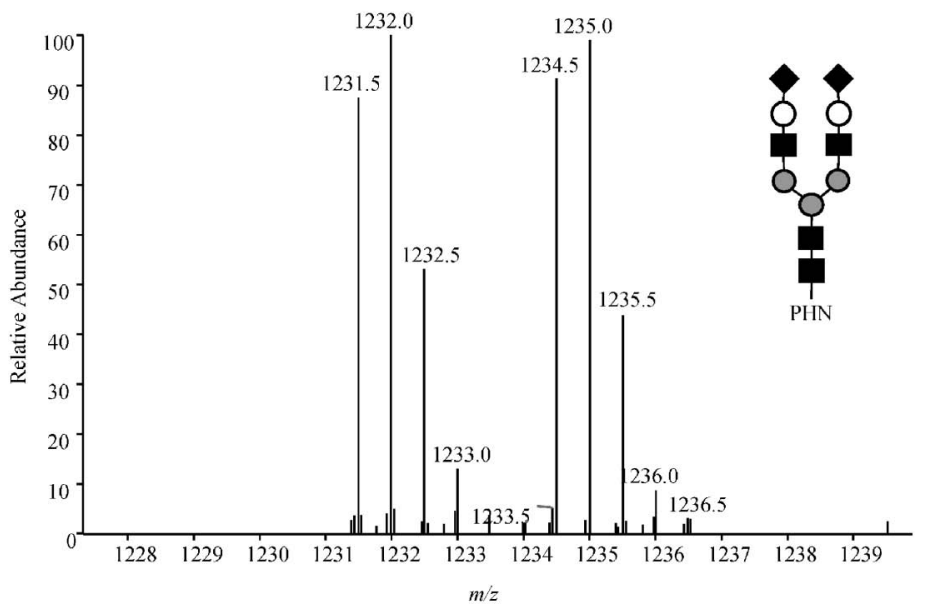

Fig. 6. Mass Spectrum of a Mixture of ${ }^{12} \mathrm{C}_{6}-\mathrm{PHN}$ and ${ }^{13} \mathrm{C}_{6}$-PHN Labeled Disialylated Core-fucosylated Complex Type Biantennary 


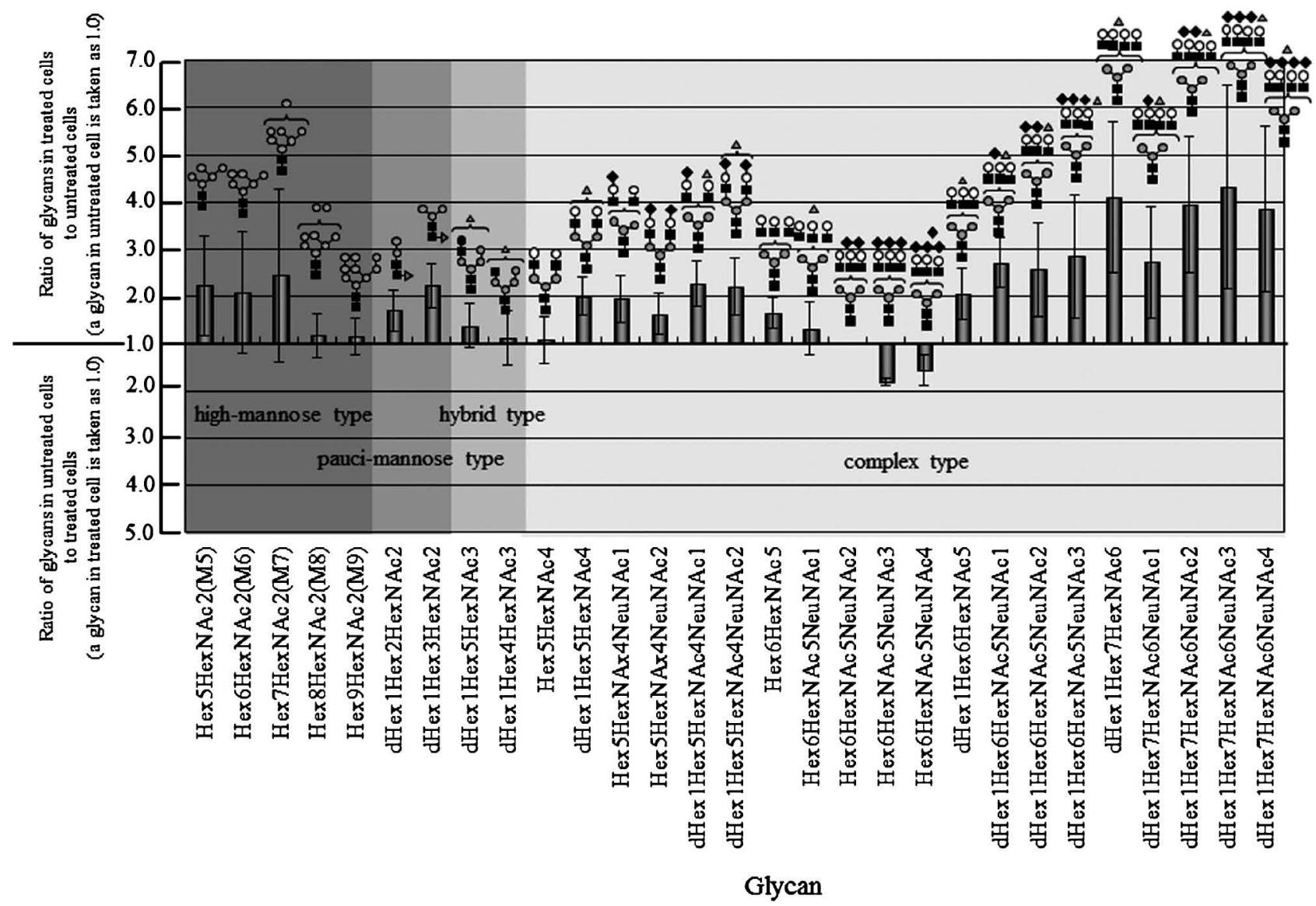

Fig. 7. Quantitative Glycan Analysis between hMSC (untreated cell) and Its Neural-lineage Cell (treated cell) Each value is the average of a triplicate. Error bars represent the standard deviations.

きたが，それらの研究を通して確立された様々な技 術が，今後，再生医療製品の品質管理手法の 1 つと しても発展していくことが期待される.

謝辞本研究は, 厚生労働科学研究費補助金並 びに科学研究費補助金若手（B）の研究成果の一部 である.

\section{REFERENCES}

1) Feizi T., Gooi H. C., Childs R. A., Picard J. K., Uemura K., Loomes L. M., Thorpe S. J., Hounsell E. F., Biochem. Soc. Trans., 12, 591 -596 (1984).

2) Kannagi R., Izawa M., Koike T., Miyazaki K., Kimura N., Cancer Sci., 95, 377-384 (2004) .

3) Lau K. S., Partridge E. A., Grigorian A., Silvescu C. I., Reinhold V. N., Demetriou M., Dennis J. W., Cell, 129, 123-134 (2007).

4) Heiskanen A., Hirvonen T., Salo H., Impola U., Olonen A., Laitinen A., Tiitinen S., Natu- nen S., Aitio O., Miller-Podraza H., Wuhrer M., Deelder A. M., Natunen J., Laine J., Lehenkari P., Saarinen J., Satomaa T., Valmu L., Glycoconj. J., 26, 367-384 (2009) .

5) Miyoshi E., Shinzaki S., Moriwaki K., Matsumoto H., Methods Enzymol., 478, 153-164 (2010).

6) Hossler P., Khattak S. F., Li Z. J., Glycobiology, 19, 936-949 (2009).

7) Hirabayashi J., Kuno A., Tateno H., Electrophoresis, 32, 1118-1128 (2011).

8) Hashii N., Kawasaki N., Itoh S., Nakajima Y., Kawanishi T., Yamaguchi T., Immunology, 126, 336-345 (2009).

9) Hashii N., Kawasaki N., Itoh S., Hyuga M., Kawanishi T., Hayakawa T., Proteomics, 5, 4665-4672 (2005).

10) Itoh S., Kawasaki N., Hashii N., Harazono A., Matsuishi, Hayakawa T., Kawanishi T., $J$. Chromatogr. A, 1103, 296-306 (2006).

11) Prockop D. J., Science, 276, 71-74 (1997). 
12) Sanchez-Ramos J., Song S., Cardozo-Pelaez F., Hazzi C., Stedeford T., Willing A., Freeman T. B., Saporta S., Janssen W., Patel N., Cooper D. R., Sanberg P. R., Exp. Neurol., 164, 247-256 (2000).

13) Tondreau T., Lagneaux L., Dejeneffe M., Massy M., Mortier C., Delforge A., Bron D., Differentiation, 72, 319-326 (2004).

14) Yuan J., Hashii N., Kawasaki N., Itoh S., Kawanishi T., Hayakawa T., J. Chromatogr. A, 1067, 145-152 (2005).

15) Xia B., Feasley C. L., Sachdev G. P., Smith D. F., Cummings R. D., Anal. Biochem., 387, 162-170 (2009).

16) Lawrence R., Olson S. K., Steele R. E., Wang L., Warrior R., Cummings R. D., Esko J. D., J. Biol. Chem., 283, 33674-33684 (2008).

17) Prien J. M., Prater B. D., Qin Q., Cockrill S. L., Anal. Chem., 82, 1498-1508 (2010).
18) Alvarez-Manilla G., Warren N. L., Abney T., Atwood J. 3rd, Azadi P., York W. S., Pierce M., Orlando R., Glycobiology, 17, 677-687 (2007).

19) Kang P., Mechref Y., Kyselova Z., Goetz J. A., Novotny M. V., Anal. Chem., 79, 60646073 (2007).

20) Zhang P., Zhang Y., Xue X., Wang C., Wang Z., Huang L., Anal. Biochem., 418, 1-9 (2011).

21) Lattova E., Perreault H., J. Chromatogr. B Analyt. Technol. Biomed. Life Sci., 793, 167179 (2003).

22) Sato S., Sakamoto T., Miyazawa E., Kikukawa Y., Tetrahedron, 60, 7899-7906 (2004) .

23) Ruhaak L. R., Steenvoorden E., Koeleman C. A., Deelder A. M., Wuhrer M., Proteomics, 10, 2330-2336 (2010). 